\title{
Synthesis and Physico-Chemical Characterization of $\mathrm{CeO}_{2} / \mathrm{ZrO}_{2}-\mathrm{SO}_{4}{ }^{2-}$ Mixed Oxides
}

\author{
Juan Manuel Hernández-Enríquez, ${ }^{1}, *$ Rebeca Silva-Rodrigo, ${ }^{1}$ Ricardo García-Alamilla, ${ }^{1}$ Luz Arcelia \\ García-Serrano, ${ }^{2}$ Brent Edward Handy, ${ }^{3}$ Guadalupe Cárdenas-Galindo, ${ }^{3}$ and Arturo Cueto-Hernández ${ }^{4}$ \\ 1 Instituto Tecnológico de Cd. Madero, División de Estudios de Posgrado e Investigación. Juventino Rosas y Jesús Urueta S/N, \\ Col. Los Mangos, 89440 Cd. Madero, Tam., México. 52833 1160-745. jmanuelher@hotmail.com \\ 2 Instituto Politécnico Nacional. Centro Interdisciplinario de Investigaciones y Estudios sobre Medio Ambiente y Desarrollo. 30 \\ de Junio \#1520, Barrio La Laguna Ticomán, 07340 México D.F., México \\ 3 CIEP, Facultad de Ciencias Químicas, Universidad Autónoma de San Luis Potosí. Av. Dr. Manuel Nava \#6, Zona \\ Universitaria, 78210 San Luis Potosí, San Luis Potosí, México \\ 4 Universidad Autónoma Metropolitana-Azcapotzalco. Av. San Pablo \#180, Col. Reynosa Tamaulipas, Delegación \\ Azcapotzalco, 02200 México D.F., México
}

Received September 16, 2011; accepted January 28, 2012

\begin{abstract}
Environmentally friendly solid-acid catalysts $\mathrm{CeO}_{2} / \mathrm{ZrO}_{2}-$ $\mathrm{SO}_{4}{ }^{2-}$ were prepared by the sol gel method varying $\mathrm{CeO}_{2}$ content $(10$, 20 and $30 \mathrm{wt} \%$ ) and using sulfation in situ, maintaining the sulfate ions amount present in the materials at $20 \mathrm{wt} \%$. $\mathrm{ZrO}_{2}$ and $\mathrm{ZrO}_{2}-\mathrm{SO}_{4}{ }^{2-}$ were also prepared for comparison proposes using the same synthesis method. The materials were characterized by X-ray diffraction, nitrogen physisorption, potentiometric titration with $n$-butylamine, decomposition of 2-propanol and $n$-pentane isomerization. The specific surface area of $\mathrm{ZrO}_{2}-\mathrm{SO}_{4}{ }^{2-}$ was high $\left(160 \mathrm{~m}^{2} / \mathrm{g}\right)$ compared with the unmodified $\mathrm{ZrO}_{2}\left(80 \mathrm{~m}^{2} / \mathrm{g}\right)$, however this area decreased with increasing the $\mathrm{CeO}_{2}$ content $\left(37-100 \mathrm{~m}^{2} / \mathrm{g}\right)$. There was no significant effect of $\mathrm{CeO}_{2}$ on the tetragonal structure of $\mathrm{ZrO}_{2}-\mathrm{SO}_{4}{ }^{2-}$. The variation of acid sites amount runs parallel to the change of specific surface area. The acid sites amount decreased with increasing cerium oxide content. The decomposition of 2-propanol results fundamentally in the formation of dehydration products such as propylene and diisopropyl ether, both involving acid sites. In addition, a good performance during the $n$-pentane isomerization was observed for these materials. The selectivity towards isopentane reaches $84 \%$ when the $\mathrm{Pt} / \mathrm{CeO}_{2} / \mathrm{ZrO}_{2}$ $\mathrm{SO}_{4}{ }^{2-}$ catalyst with the highest $\mathrm{CeO}_{2}$ content was used.

Key words: Mixed oxides, sol-gel method, sulfation, physico-chemical characterization, acid-base properties.
\end{abstract}

\section{Introduction}

Mixed oxide catalysts have received tremendous attention both in fundamental and industrial point of view because of their wide spread utility in the chemical industry in comparison with bulk oxide catalysts [1]. The synthesis and development of materials with enhanced thermal, redox and acid-base properties are of paramount interest in designing and selecting catalysts for specific catalytic reactions [2-6]. Recently, a new generation of mixed oxides containing $\mathrm{CeO}_{2}$ and $\mathrm{ZrO}_{2}$ with the features previously mentioned has been developed [7-10]. The ceriazirconia systems have been recognized as key materials for various applications in catalysis, as ceramics, in fuel cell technology, as solid state electrolytes and as a catalytic promoter in three-way catalysts [11-14]. The selection of an appropriate method of synthesis plays an important role in the success of
Resumen. Se prepararon por el método sol-gel catalizadores sólidos-ácidos tipo $\mathrm{CeO}_{2} / \mathrm{ZrO}_{2}-\mathrm{SO}_{4}{ }^{2-}$ amigables con el medio ambiente, variando el contenido del $\mathrm{CeO}_{2}(10,20$ y $30 \%$ peso), usando sulfatación in situ y manteniendo la cantidad de iones sulfato en $20 \%$ peso. Utilizando el mismo método y para propósitos de comparación se sintetizaron $\mathrm{ZrO}_{2}$ y $\mathrm{ZrO}_{2}-\mathrm{SO}_{4}{ }^{2-}$. Los materiales se caracterizaron por difracción de rayos $\mathrm{X}$, fisisorción de nitrógeno, titulación potenciométrica con $n$-butilamina, descomposición de 2-propanol e isomerización de $n$-pentano. El área específica de la $\mathrm{ZrO}_{2}-\mathrm{SO}_{4}{ }^{2-}$ fue más alta $\left(160 \mathrm{~m}^{2} / \mathrm{g}\right)$ en comparación con la $\mathrm{ZrO}_{2}$ pura $\left(80 \mathrm{~m}^{2} / \mathrm{g}\right)$, sin embargo, esta área decrece con el incremento en el contenido de $\mathrm{CeO}_{2}$ $\left(37-100 \mathrm{~m}^{2} / \mathrm{g}\right)$. El $\mathrm{CeO}_{2}$ no presento un efecto significativo sobre la estructura tetragonal de la $\mathrm{ZrO}_{2}-\mathrm{SO}_{4}{ }^{2-}$. La variación en la cantidad de los sitios ácidos disminuye a la par con el cambio de área específica. La cantidad de sitios ácidos decrece con el incremento de óxido de cerio. La descomposición del 2-propanol resulto en la formación de productos de deshidratación, propileno y diisopropil éter, ambos envolviendo sitios ácidos. Los materiales sintetizados presentaron un buen comportamiento durante la isomerización de $n$-pentano y la selectividad hacia isopentano alcanzó el $84 \%$ con el catalizador con mayor contenido de $\mathrm{CeO}_{2}$.

Palabras clave: Óxidos mixtos, método sol-gel, sulfatación, caracterización fisicoquímica, propiedades ácido-base.

these materials in the field of catalysis. Several wet-chemical methods, such as hydrothermal synthesis, high-energy mechanical milling, polymerized complex method, coprecipitation, solgel and forced cohydrolysis have been applied to prepare the $\mathrm{CeO}_{2}-\mathrm{ZrO}_{2}$ mixed oxides [15-19]. Literature reports indicate that among these synthesis methods, hydrothermal synthesis, polymerized complex method, sol-gel and forced cohydrolysis allow to obtain compositionally homogeneous materials [20]. On the other hand, it can also be noted that besides its redox properties, ceria-zirconia materials present remarkable acidbase properties which have not been investigated extensively. A method to improve the acidic properties of $\mathrm{CeO}_{2}-\mathrm{ZrO}_{2}$ materials is the preparation of mixed oxides as $\mathrm{CeO}_{2} / \mathrm{ZrO}_{2}-\mathrm{SO}_{4}{ }^{2-}$. It has been found by means the ammonia-TPD experiments that sulfation of ceria-zirconia mixed oxide can generate the formation of super-acidic sites [21]. Many chemical methods have 
been developed to measure the acid-base surface properties of the oxides. For this purpose, alkane isomerization and the conversion of secondary alcohols are used [22-25].

The aim of this work is to study the effect of the $\mathrm{CeO}_{2}$ loading on the physico-chemical properties of $\mathrm{ZrO}_{2}-\mathrm{SO}_{4}{ }^{2-}$ and explore the possibility of using $\mathrm{CeO}_{2} / \mathrm{ZrO}_{2}-\mathrm{SO}_{4}{ }^{2-}$ as an acidbase bi-functional catalyst.

\section{Results and discussion}

\section{Structural properties}

The X-ray diffraction patterns of pure $\mathrm{CeO}_{2}$ and $\mathrm{ZrO}_{2}$ calcined at $600{ }^{\circ} \mathrm{C}$ for $3 \mathrm{~h}$ are shown in Fig. 1 and Fig. 2, respectively. XRD pattern of $\mathrm{CeO}_{2}$ consists of six main reflections on the $2 \theta$ scale, $28.57^{\circ}, 33.00^{\circ}, 47.60^{\circ}, 56.39^{\circ}, 59.13^{\circ}$ and $69.51^{\circ}$ corresponding to (111), (200), (220), (311), (222) and (400) planes, respectively. The diffraction peaks are characteristic of the cubic ceria phase with fluorite structure (JCPDS card number 34-394). Additional XRD lines assigned to ceria precursor were observed at $2 \theta=38.19^{\circ}$ and $44.22^{\circ}$. XRD pattern of pure zirconia (Z100) exhibits intense peaks at $2 \theta=30.26^{\circ}, 35.10^{\circ}$,

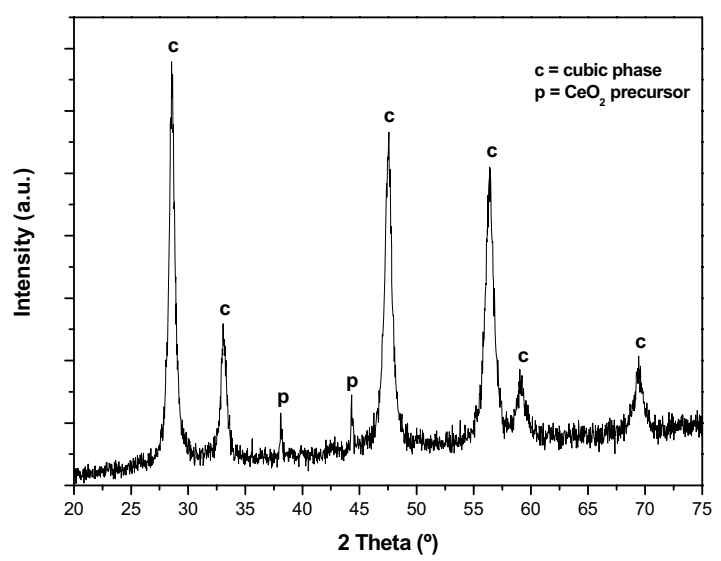

Fig. 1. XRD pattern of $\mathrm{CeO}_{2}$.

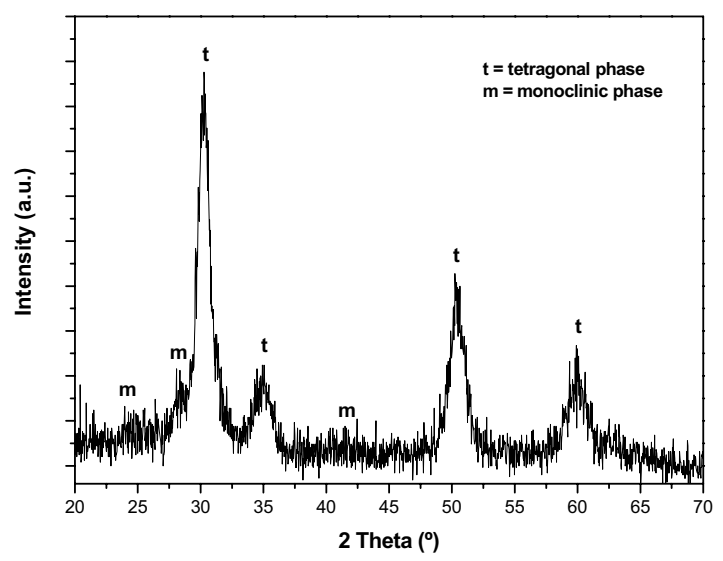

Fig. 2. XRD pattern of $\mathrm{ZrO}_{2}$. $50.42^{\circ}$ and $60.04^{\circ}$ attributed to the tetragonal phase of zirconia corresponding to (101), (110), (112) and (211) planes (JCPDS card number 80-2155), respectively. In addition, the pattern of zirconia shows others small peaks at $2 \theta=24.50^{\circ}, 28.36^{\circ}$ and $41.55^{\circ}$, which are related to the monoclinic phase (JCPDS card number 7-3430). These results suggest that tetragonal and monoclinic phases coexisted in this sample. Fig. 3 displays the diffractograms of the $\mathrm{CeO}_{2} / \mathrm{ZrO}_{2}-\mathrm{SO}_{4}{ }^{2-}$ mixed oxides, which clearly exhibit the tetragonal phase as the main one. Introduction of less than 20 wt.\% of $\mathrm{CeO}_{2}$ into sulfated zirconia matrix did not involved any appreciable phase modification in the material. However, at $\mathrm{CeO}_{2}$ loadings exceeding $20 \mathrm{wt} . \%$, small peaks at $2 \theta=25.01^{\circ}, 26.20^{\circ}$ and $31.18^{\circ}$ attributed to the monoclinc phase of zirconia were detected. The absence of the characteristic diffracction peaks related to cubic fluorite phase of $\mathrm{CeO}_{2}$ means that the ceria particles were too small to be detected by XRD or the ceria particles were well dispersed on the mixed oxide. The crystallite size of the synthesized materials was determined applying Scherrer's equation, calculated from the full width at half maximum intensity (FWHM) of the mean reflection (101). The average crystallite size of these materials was in the range 6.5-8.5 $\mathrm{nm}$ (Table 1).

\section{Textural properties}

All synthesized oxides $\left(\mathrm{ZrO}_{2}, \mathrm{ZrO}_{2}-\mathrm{SO}_{4}{ }^{2-}\right.$ and $\mathrm{CeO}_{2} / \mathrm{ZrO}_{2}-$ $\mathrm{SO}_{4}{ }^{2-}$ ) calcined at $600{ }^{\circ} \mathrm{C}$ present the same nitrogen adsorption-

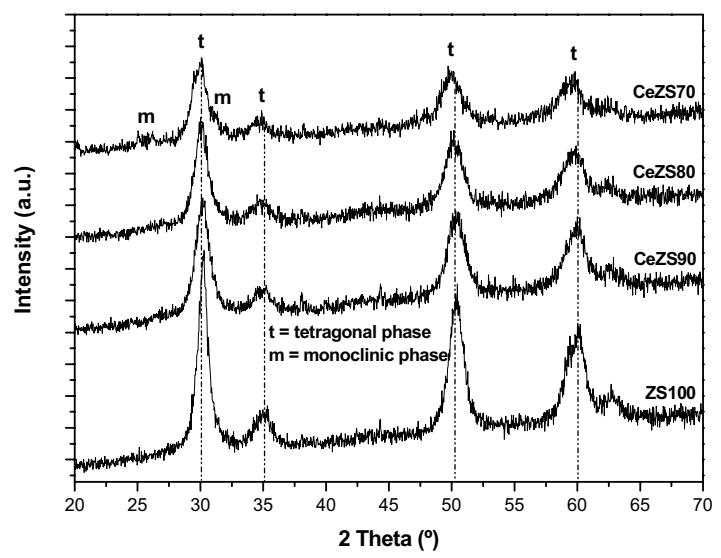

Fig. 3. XRD patterns of $\mathrm{CeO}_{2} / \mathrm{ZrO}_{2}-\mathrm{SO}_{4}{ }^{2-}$ mixed oxides.

Table 1. Parameters of synthesis, textural properties and crystallite size of $\mathrm{ZrO}_{2}, \mathrm{ZrO}_{2}-\mathrm{SO}_{4}{ }^{2-}$ and $\mathrm{CeO}_{2} / \mathrm{ZrO}_{2}-\mathrm{SO}_{4}{ }^{2-}$.

\begin{tabular}{cccccc}
\hline Sample & $\begin{array}{c}\mathrm{CeO}_{2} \\
(\text { wt.\% })\end{array}$ & $\begin{array}{c}\text { Surface } \\
\text { area } \\
\left(\mathrm{m}^{2} / \mathrm{g}\right)\end{array}$ & $\begin{array}{c}\text { Poro } \\
\text { diameter } \\
(\AA)\end{array}$ & $\begin{array}{c}\text { Poro } \\
\text { volume } \\
\left(\mathrm{cm}^{3} / \mathrm{g}\right)\end{array}$ & $\begin{array}{c}\text { Crystallite } \\
\text { size } \\
(\mathrm{nm})\end{array}$ \\
\hline Z100 & - & 80 & 257 & 0.51 & 6.8 \\
ZS100 & - & 160 & 139 & 0.56 & 7.5 \\
CeZS90 & 10 & 100 & 116 & 0.29 & 7.8 \\
CeZS80 & 20 & 74 & 96 & 0.18 & 6.4 \\
CeZS70 & 30 & 37 & 189 & 0.17 & 8.5 \\
\hline
\end{tabular}


desorption isotherms. The nitrogen isotherm and the textural properties of the materials are respectively given in the Fig. 4 and Table 1. The synthesized samples showed a type III isotherm with very reduced hysteresis loop, which is convex whit respect to relative pressure $\left(p / p_{0}\right)$ over its entire range [27,28]. Type III isotherms are obtained from non-porous solids or solids with macroporous, though also exist the possibility that the samples have some mesoporous in its morphological structure [29]. The only difference on the isotherms of these materials is in the absorbed volumes, which show different specific surface area results. The first striking difference appears form the comparison between the areas of the pure zirconia (Z100) and sulfated zirconia sample (ZS100). The specific surface area pertaining to ZS100 is about two times larger than the of Z100 calcined at the same temperature. The present larger area of the ZS100 sample can be related to the presence of the $\mathrm{SO}_{4}{ }^{2-}$ ions which improves the thermal stability into $\mathrm{ZrO}_{2}$ and inhibits the strong syntherization on the material, this result is in agreement with the reported by Yori et al [30]. It has been suggested by Wang et al. that when the sulfuric acid has been used as a synthesis catalyst, the $\mathrm{SO}_{4}{ }^{2-}$ ions present in the $\mathrm{Zr}-\mathrm{O}$ framework would replace for $\mathrm{OH}^{-}$ions. Because the thermal stability of the sulfate to the zirconium linkages is much higher than that hydroxyl bridges across two $\mathrm{Zr}$ atoms, the removal of $\mathrm{SO}_{4}{ }^{2-}$ ions needs a higher temperature in comparison with the hydroxyl ions, which delays the material syntherization and also stabilizes the tetragonal phase at low-temperature [19]. The second difference appears from the comparison between the areas of the $\mathrm{ZrO}_{2}-\mathrm{SO}_{4}{ }^{2-}$ and $\mathrm{CeO}_{2} / \mathrm{ZrO}_{2}-\mathrm{SO}_{4}{ }^{2-}$ mixed oxides. It can be seen that, for all mixed oxides the specific surface areas were always significantly lower than that of $\mathrm{ZrO}_{2}-\mathrm{SO}_{4}{ }^{2-}$. The specific surface area decrease as a function of $\mathrm{CeO}_{2}$ content and may be caused due to the formation of agglomerates during the synthesis. On the other hand, the sample with the highest $\mathrm{CeO}_{2}$ content (CeZS70) appeared with an intense yellowish color; it may be inferred to the formation of more $\mathrm{CeO}_{2}$ crystallites on the sample which might reduces the surface mobility of $\mathrm{ZrO}_{2}-\mathrm{SO}_{2}{ }^{4-}$, thus enhancing the sintering and reducing the

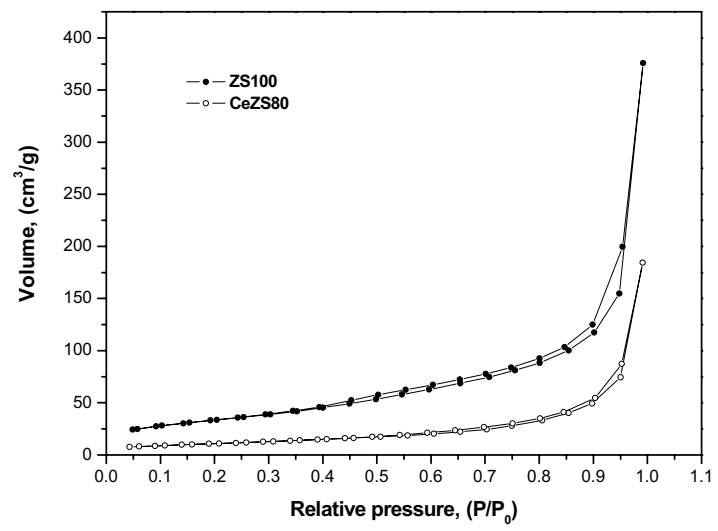

Fig. 4. Nitrogen adsorption-desorption isotherms of $\mathrm{ZrO}_{2}-\mathrm{SO}_{4}{ }^{2-}$ and $\mathrm{CeO}_{2} / \mathrm{ZrO}_{2}-\mathrm{SO}_{4}{ }^{2-}$ materials. surface area.

\section{Acidic properties}

The potentiometric titration method with $n$-butylamine allowed evaluating the surface acidity of the different synthesized materials. The maximum acid strength (M.A.S.) was determined from the potential reading $(\mathrm{mV})$ at the first point of the titration run. The final amount of titrant used (meq/g-solid) that corresponds to the point at which a plateau is reached indicates the total number of the acid sites [26]. As a criterion for interpreting the results obtained, the acid strength can be assigned according to the following scale: M.A.S. $>100 \mathrm{mV}$, very strong acid sites; $0<$ M.A.S. $<100 \mathrm{mV}$, strong acid sites; $-100 \mathrm{mV}$ $<$ M.A.S. $<0 \mathrm{mV}$, weak acid sites and M.A.S. $<-100 \mathrm{mV}$, very weak acid sites [31]. In Fig. 5 the remarkable difference in acid strength between pure zirconia (Z100) and sulphated oxides $\left(\mathrm{ZrO}_{2}-\mathrm{SO}_{4}{ }^{2-}\right.$ and $\left.\mathrm{CeO}_{2} / \mathrm{ZrO}_{2}-\mathrm{SO}_{4}{ }^{2-}\right)$ can be noted from the milivolts range. Pure zirconia is a weakly acidic oxide $(E$ $=5 \mathrm{mV}$ ) but it is modified by the $\mathrm{SO}_{4}{ }^{2-}$ ions addition, which generates strong acidic sites on the zirconia surface according to the scale mentioned by Pizzio et al., [31]. In the case of $\mathrm{ZrO}_{2}$ $\mathrm{SO}_{4}{ }^{2-}$ (ZS100), the initial potential value was $560 \mathrm{mV}$; slightly lower than that the corresponding to $\mathrm{CeO}_{2} / \mathrm{ZrO}_{2}-\mathrm{SO}_{4}{ }^{2-}$ materials (451-549 mV). From Fig. 6, it can be observed that the addition of $\mathrm{Ce}_{2} \mathrm{O}$ decrease the number of the acid sites on the $\mathrm{ZrO}_{2}-\mathrm{SO}_{4}{ }^{2-}$ surface. Total acidity decrease in the same order that $\mathrm{CeO}_{2}$ content was increased in the sulfated materials.

\section{2-propanol dehydration}

The acid-base properties of $\mathrm{ZrO}_{2}, \mathrm{ZrO}_{2}-\mathrm{SO}_{4}{ }^{2-}$ and $\mathrm{CeO}_{2}-\mathrm{ZrO}_{2}-$ $\mathrm{SO}_{4}{ }^{2-}$ catalysts are deduced from their catalytic behavior in 2-propanol decomposition and the results are given in Fig. 7. Through the selectivity of this reaction it was deduced which sites predominated in the synthesized materials. As suggest by literature, the dehydration of 2-propanol to produce propylene and diisopropyl ether is assumed to proceed on acidic sites,

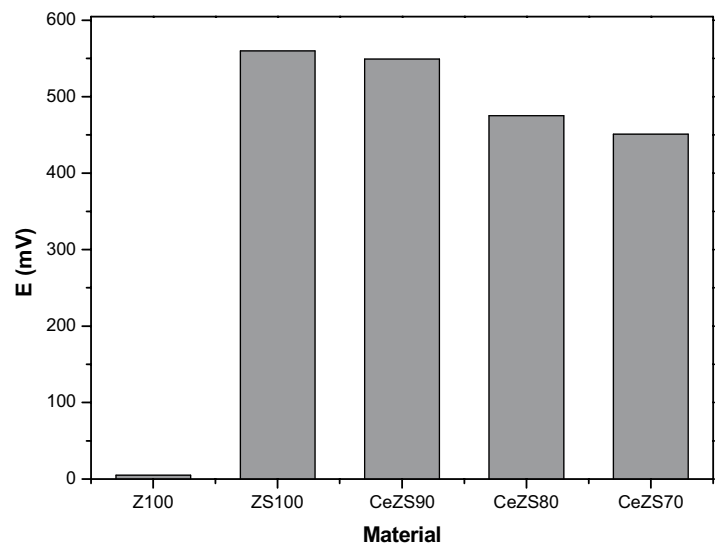

Fig. 5. Maximum acid strength of $\mathrm{ZrO}_{2}, \mathrm{ZrO}_{2}-\mathrm{SO}_{4}{ }^{2-}$ and $\mathrm{CeO}_{2} / \mathrm{ZrO}_{2}-$ $\mathrm{SO}_{4}{ }^{2-}$ materials determined by potentiometric titration with $n$-butylamine. 
whereas its dehydrogenation to acetone is presumed to be catalyzed by basic sites in inert atmosphere [32]. It is clear that the variations in catalytic activities of the samples are roughly correlated with the changes of their acid amount sites and with the specific surface area obtained on the catalyst. As can be seen from Fig. 7, the $\mathrm{ZrO}_{2}-\mathrm{SO}_{4}{ }^{2-}(\mathrm{ZS} 100)$ exhibits a higher catalytic activity than mixed oxides $\left(\mathrm{CeO}_{2} / \mathrm{ZrO}_{2}-\mathrm{SO}_{4}{ }^{2-}\right)$. The catalytic activity of all mixed oxides was similar indicating that they contain at the surface a very small concentration of extremely acid sites responsible practically of their lower conversions. The nature, density and strength of surface acid sites of these materials could be related to the $\mathrm{CeO}_{2}$ content. The decomposition of 2-propanol results fundamentally, in the formation of dehydration products such as propylene and diisopropyl ether, both involving acid sites. Depending on the $\mathrm{CeO}_{2}$ content in the catalytic supports, the selectivity to diisopropyl ether fluctuated in the range between 76 and $96 \%$. Pure zirconia (Z100) was not able to transforms the alcohol at the same temperature than the sulfated materials. However, Z100 catalyzed the dehydration of 2-propanol to propylene at $120{ }^{\circ} \mathrm{C}$ with very low conversion $(0.11 \%)$. In accordance with the selectivity pattern observed in

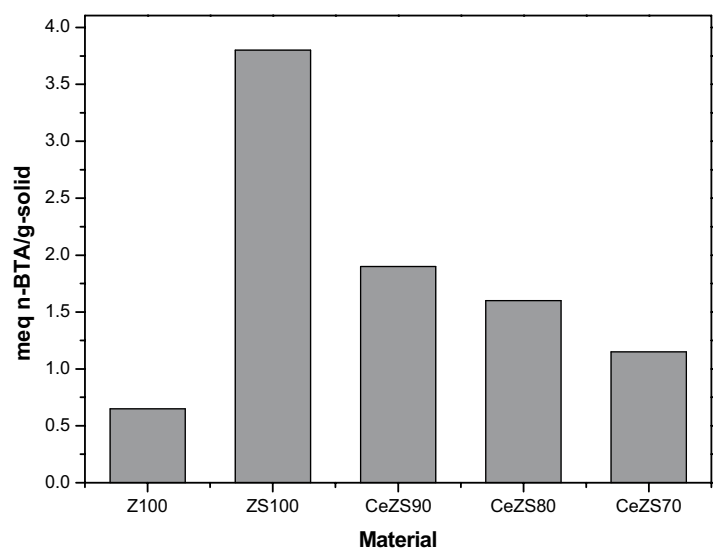

Fig. 6. Total acidity of $\mathrm{ZrO}_{2}, \mathrm{ZrO}_{2}-\mathrm{SO}_{4}{ }^{2-}$ and $\mathrm{CeO}_{2} / \mathrm{ZrO}_{2}-\mathrm{SO}_{4}{ }^{2-}$ materials determined by potentiometric titration with $n$-butylamine.

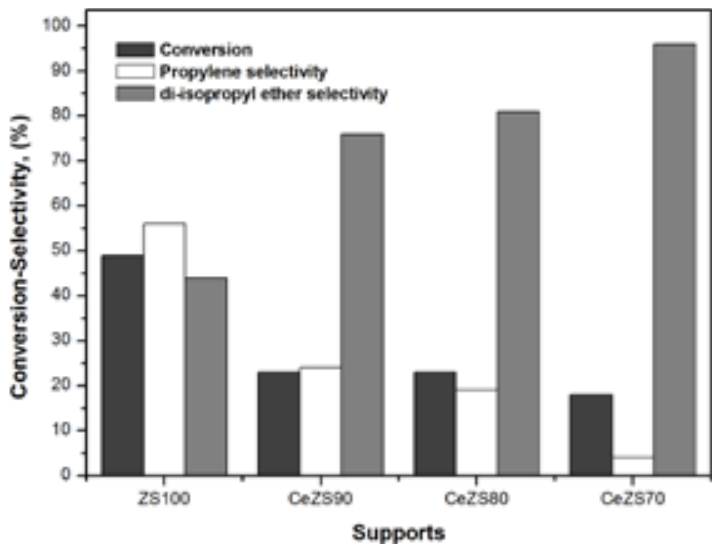

Fig. 7. 2-Propanol dehydration, $\mathrm{T}=80^{\circ} \mathrm{C}, \mathrm{P}=1 \mathrm{~atm}, \mathrm{WHSV}=1.5$ $\mathrm{h}^{-1}$, reaction time $=2 \mathrm{~h}$.
Fig. 7, it can be concluded that all synthesized materials had an acid character. Even though it has been reported that $\mathrm{ZrO}_{2}$ presents amphoteric properties [33], in this work there was not acetone production which indicated no basic sites in the materials or if they existed, they do not have the sufficient strength to direct the reaction toward the dehydrogenation of the alcohol.

\section{$n$-pentane isomerization}

The catalytic properties of $\mathrm{Pt} / \mathrm{ZrO}_{2}-\mathrm{SO}_{4}{ }^{2-}$ and $\mathrm{Pt} / \mathrm{CeO}_{2} / \mathrm{ZrO}_{2}-$ $\mathrm{SO}_{4}{ }^{2-}$ mixed oxide catalysts were tested in the $n$-pentane isomerization reaction at $250{ }^{\circ} \mathrm{C}$ and atmospheric pressure. Fig. 8 shows conversion and products selectivity in this reaction for these materials. $\mathrm{Pt} / \mathrm{ZrO}_{2}$ is not active for the reaction; however, $\mathrm{Pt} / \mathrm{ZrO}_{2}-\mathrm{SO}_{4}{ }^{2-}$ and all $\mathrm{Pt} / \mathrm{CeO}_{2} / \mathrm{ZrO}_{2}-\mathrm{SO}_{4}{ }^{2-}$ mixed oxide catalysts show catalytic activities with a product distribution where iso-pentane is a main product and $n$-propane, $n$-butane, iso-butane also were observed in smaller amounts. These results show that this reaction is a typical acid-catalyzed reaction and these solid acid catalysts are effective for this reaction. The activity order of all $\mathrm{Pt} / \mathrm{CeO}_{2} / \mathrm{ZrO}_{2}-\mathrm{SO}_{4}{ }^{2-}$ catalysts is as follows: $\mathrm{Pt} /$ $\mathrm{ZS} 100>\mathrm{Pt} / \mathrm{CeZS} 90>\mathrm{Pt} / \mathrm{CeZS} 80>\mathrm{Pt} / \mathrm{CeZS70}$. For Pt $/ \mathrm{CeO}_{2} /$ $\mathrm{ZrO}_{2}-\mathrm{SO}_{4}{ }^{2-}$ catalysts, the catalytic activity reduce gradually with increased $\mathrm{CeO}_{2}$ loading, in agreement with the decrease in the specific surface area and surface acidity. The high activity of the $\mathrm{Pt} / \mathrm{ZrO}_{2}-\mathrm{SO}_{4}{ }^{2-}$ (Pt/ZS100) catalyst may be ascribed to its excellent total acidity and tetragonal crystalline $\mathrm{ZrO}_{2}$ phase. Although it has been reported by many researches that the sulfated $\mathrm{ZrO}_{2}$ of metastable tetragonal phase has higher catalytic activity than the monoclinic phase in many reactions such as the isomerization of $n$-paraffins [34-39], it is more important to consider the relation between the presence of crystallite defects and the stabilization of the tetragonal structure. Tetragonal structure in catalyst promoted in the state of amorphous gel is a consequence of the stabilization of anionic vacancies by sulfate ions. Catalytic activity is supposedly related to charge abstraction and stabilization from radical and ionic intermediates, a process enabled or enhanced by anionic vacancies in tetragonal zirconia catalysts [40]. On the other hand, for all catalysts

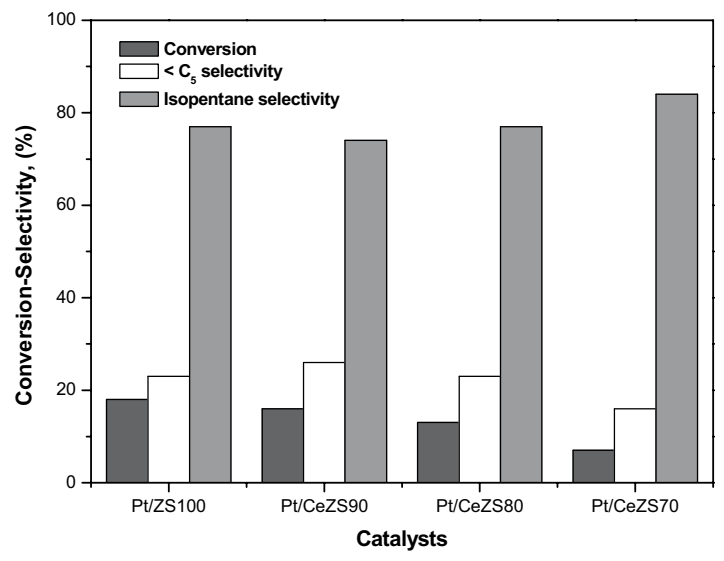

Fig. 8. $n$-pentane isomerization conversion and selectivity, evaluated at $\mathrm{T}=250{ }^{\circ} \mathrm{C}, \mathrm{P}=1 \mathrm{~atm}$, WHSV $=0.5 \mathrm{~h}^{-1}$, reaction time $=3 \mathrm{~h}$. 


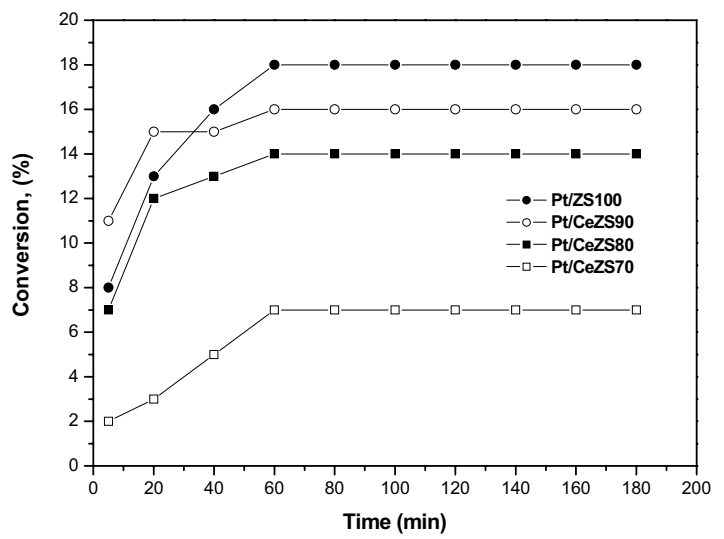

Fig. 9. $n$-pentane isomerization, $\mathrm{T}=250{ }^{\circ} \mathrm{C}, \mathrm{P}=1 \mathrm{~atm}, \mathrm{WHSV}=0.5$ $\mathrm{h}^{-1}$, reaction time $=3 \mathrm{~h}$.

a steady state is reached after a transitory period of $60 \mathrm{~min}$, characterized by an increase of the catalytic activity (Fig. 9). At the same time, the selectivity of isomerization product grows. The induction period observed might be attributed to the formation of the reaction intermediates on the catalyst surface. After of the transitory time, the conversion was constant with the increase of time, which indicates a good catalytic stability in the solids at the evaluated conditions reactions, may be due to Pt presence. Tomishige et al. have suggested that molecular hydrogen fed to the isomerization reaction dissociates on the platinum to hydrogen atoms, which undergo spillover onto the acid support and convert to an $\mathrm{H}^{+}$and an $\mathrm{e}^{-}$or $\mathrm{H}^{-}$. The role of spilt-over hydrogen is the regeneration of Brönsted acid sites and the supply of hydride to carbenium ion intermediate before $\beta$-scission events occur, avoiding cracking and polymerization reactions and thus Pt induces the reaction stability [41].

In Fig. 8 it can be observed that the selectivity to iso-pentane was higher than $70 \%$ for all tested materials. The maximum selectivity toward the main product $\left(i-\mathrm{C}_{5}\right)$ was obtained when the $\mathrm{CeO}_{2}$ content reached 30 wt.\% in the catalyst, however, this material present the lowest conversion. The promoter effect of $\mathrm{CeO}_{2}$ on the selectivity of this reaction is probably due to the decrease of density and strength of the surface acid sites. The cause of the promotion effect is still not clear.

\section{Conclusions}

The results showed that the interaction between sulphated zirconia and ceria influenced the physicochemical properties of synthesized mixed oxides. The presence of ceria and sulfate ions delays the phase transition of $\mathrm{ZrO}_{2}$ from tetragonal to monoclinic. The specific surface area and acidity of mixed oxides decrease in proportion to the ceria content. There was a good correlation between catalytic activity and acidity for the probe reactions, 2-propanol dehydration and $n$-pentane isomerization. The probe reactions provide strong evidence that the surface of the mixed oxide had an acid character. Specifically 2-propanol conversion reaction, results fundamentally in the formation of dehydration products such as propylene and diisopropyl ether, both involving acid sites. On the other hand, in $n$-pentane isomerization, the cracking products were greatly inhibited, while a large amount of iso-pentane was produced on the moderate acidic surface of mixed oxides. The best conversion of $n$-pentane could be as high as $16 \%$ over the Pt/CeZS90 catalyst and the highest selectivity towards iso-pentane formation $(84 \%)$ was obtained with the material Pt/CeZS70.

\section{Experimental}

\section{Mixed oxides preparation}

The mixed oxides $\mathrm{CeO}_{2} / \mathrm{ZrO}_{2}-\mathrm{SO}_{4}{ }^{2-}$ investigated in this work were synthesized by the sol-gel method, varying the $\mathrm{CeO}_{2}$ content $(10,20$ and 30 wt.\%). The sol-gel synthesis was carried out as follows: Cerium acetate $\left[\left(\mathrm{CH}_{3} \mathrm{CO}_{2}\right)_{3} \mathrm{Ce} \cdot \mathrm{H}_{2} \mathrm{O}\right.$; Sigma-Aldrich; 99.99\%] was previously dissolved in a mixture of tert-butyl alcohol [( $\left.\mathrm{CH}_{3}\right)_{3} \mathrm{COH}$; Sigma-Aldrich; 99.9\%)] and deionized water. After that, the mixture was vigorously stirred by means of a magnetic stirrer and refluxed at $70{ }^{\circ} \mathrm{C}$ for $1 \mathrm{~h}$. A predetermined amount of zirconium $n$-butoxide $\left(\mathrm{Zr}\left[\mathrm{O}\left(\mathrm{CH}_{2}\right)_{3} \mathrm{CH}_{3}\right]_{4}\right.$; Sigma-Aldrich; 80 wt.\% in 1-butanol) dissolved in tert-butyl alcohol was added drop-wise and the system was maintained in continuous stirring and reflux at $70{ }^{\circ} \mathrm{C}$ for 2 $\mathrm{h}$. During the last step, sulfation was carried out in situ using concentrated $\mathrm{H}_{2} \mathrm{SO}_{4}$ as sulfating agent, maintaining the sulfate ions amount constant at $20 \mathrm{wt} \% \%$ on the final material. The resulting gel was then aged for $24 \mathrm{~h}$ and dried in static conditions at $120^{\circ} \mathrm{C}$ for $24 \mathrm{~h}$. The synthesized materials in powder form were calcined in a dynamic air atmosphere at $600{ }^{\circ} \mathrm{C}$ for $3 \mathrm{~h}$. Pure and sulfated zirconia $\left(\mathrm{ZrO}_{2}\right.$ and $\left.\mathrm{ZrO}_{2}-\mathrm{SO}_{4}{ }^{2-}\right)$ were also prepared for comparison proposes using the same synthesis method. Synthesized mixed oxides were named according to the sulfation agent and the weight percentage of $\mathrm{CeO}_{2}$ present in the material, its nomenclature is shown in the Table 1.

For the $n$-pentane isomerization, the mixed oxides $\mathrm{CeO}_{2} /$ $\mathrm{ZrO}_{2}-\mathrm{SO}_{4}{ }^{2-}$ were impregnated with platinum $(\mathrm{Pt})$ by means of incipient wetness method from a platinum acetylacetonate solution [ $\mathrm{Pt}\left(\mathrm{C}_{5} \mathrm{H}_{7} \mathrm{O}_{2}\right)_{2}$; Sigma-Aldrich; 99.99\%] followed by drying at $120{ }^{\circ} \mathrm{C}$ for $6 \mathrm{~h}$ and calcination in air flow at $400{ }^{\circ} \mathrm{C}$ for $3 \mathrm{~h}$. The theoretical concentration of $\mathrm{Pt}$ was fixed in 0.3 wt. $\%$ for all catalysts.

\section{Physico-chemical characterization}

Powder X-ray diffraction patterns were recorded on a Bruker diffractometer using $\mathrm{Cu} \mathrm{K} \alpha$ radiation $(\lambda=1.5406 \AA)$ and a graphite secondary beam monochromator; the intensities of the diffracction lines were obtained in the $2 \theta$ range between 20 and $70^{\circ}$ with a step size of $0.02^{\circ}$ and a measuring time of $2.7 \mathrm{~s}$ per point. The crystallite size of the materials was determined by the Scherrer's equation.

Nitrogen physisorption was used to determine the specific surface areas of the materials at the temperature of liquid ni- 
trogen $\left(-196{ }^{\circ} \mathrm{C}\right)$ in a Quantachrome Autosorb-1 instrument. Prior to the measurements, samples were outgassed at $350{ }^{\circ} \mathrm{C}$ for $2 \mathrm{~h}$. The specific surface area was calculated using the BET equation and the $\mathrm{BJH}$ method was used to calculate the average pore diameter and the pore volume of the samples.

Materials acidity was determined by potentiometric titration with $n$-butylamine. A small quantity of $0.025 \mathrm{M} n$-butylamine in acetonitrile was added to a known mass of solid, and agitated for $3 \mathrm{~h}$. Later, the suspension was titrated with the same base at $0.2 \mathrm{ml} / \mathrm{min}$. The electrode potential variation was measured with a JENWAY-3310 digital $\mathrm{pH}$ meter. The voltage is recorded at intervals as the titrant is added and plotted against the amount of base used. The potentiometric titration method reported in this study has been described in detail previously by Cid and Pecchi [26].

2-propanol dehydration was carried out in a fixed-bed reactor operating at $80^{\circ} \mathrm{C}$ and atmospheric pressure. Approximately $0.1 \mathrm{~g}$ of the catalyst was loaded into the reactor. Prior to the reaction, the catalyst was preheated at $350{ }^{\circ} \mathrm{C}$ for $1 \mathrm{~h}$ in a purified nitrogen flow. During the reaction, an effluent collected periodically was analyzed by Varian 3400 gas chromatograph equipped with a FID detector and a column packed with Carbowax 1540 on Chromosorb (1.5 m length and $3.18 \mathrm{~mm}$ I.D.).

The $n$-pentane isomerization was carried out in a fixedbed reactor, operating at $250{ }^{\circ} \mathrm{C}$ and atmospheric pressure. The catalyst $(0.3 \mathrm{~g})$ was reduced at $350{ }^{\circ} \mathrm{C}$ for $1 \mathrm{~h}$ in a flow of hydrogen prior to running the test reaction. The products were analyzed on-line by a Varian 3400 gas chromatograph equipped with a FID detector and a column packed with 23 SP-1700 on 80/100 Chromosorb (6 $\mathrm{m}$ length and $3.18 \mathrm{~mm}$ I.D.).

\section{References}

1. Burri, D. R.; Choi, K. M.; Lee, J. H.; Han, D. S.; Park, S. E. Catal. Commun. 2007, 8, 43-48.

2. Brayner, R.; Ciuparu, D.; da Cruz, G. M.; Fiévet, F.; Bozon, F. Catal. Today 2000, 57, 261-266.

3. Reddy, B. M.; Sreekanth, P. M.; Lakshmanan, P.; Khan, A. J. Mol. Catal. A: Chem. 2006, 244, 1-7.

4. Liu, Ch.; Luo, L.; Lu, X. Kinet. Catal. 2008, 49, 676-681.

5. Ji, Y.; Toops, T. J.; Crocker, M. Catal. Lett. 2009, 127, 55-62.

6. Gao, X.; Jiang, Y.; Fu, Y.; Zhong, Y.; Luo, Z.; Cen, K. Catal. Commun. 2010, 11, 465-469.

7. Takeguchi, T.; Furukawa, S.; Inoue, M. J. Catal. 2001, 202, 1424.

8. Bedrane, S.; Descorme, C.; Duprez, D. Catal. Today 2002, 75, 401-405.

9. Zhao, M.; Shen, M.; Wang, J. J. Catal. 2007, 248, 258-267.

10. Mejri, I.; Younes, M. K.; Ghorbel, A.; Eloy, P.; Gaigneaux, E. M. J. Porous Mater. 2009, 16, 745-748.

11. Bozo, Ch.; Guilhaume, N.; Herrmann, J. M. J. Catal. 2001, 203, 393-406.
12. Prasad, D. H.; Lee, J. H.; Lee, H. W.; Kim, B. K.; Park, J. S. J. Ceramic. Process. Res. 2009, 10, 748-752.

13. Haneda, M.; Houshito, O.; Sato, T.; Takagi, H.; Shinoda, K.; Nakahara, Y.; Hiroe, K.; Hamada, H. Catal. Commun. 2010, 11, 317-321.

14. Vagia, E. Ch.; Lemonidou, A. A. J. Catal. 2010, 269, 388-396.

15. Thammachart, M.; Meeyoo, V.; Risksomboon, T.; Osuwan, S. Catal. Today 2001, 68, 53-61.

16. Suda, A.; Ukyo, Y.; Sobukawa, H.; Sugiura, M. Rev. Toyota CRDL 2002, 3, 6-13.

17. Adamski, A.; Djéga, G.; Sojka, Z. Catal. Today 2007, 119, 120124.

18. Reddy, B. M.; Patil, M. K.; Lakshmanan, P. J. Mol. Catal. A: Chem. 2006, 256, 290-294.

19. Wang, J. A.; González, G.; Chen, L.; Valenzuela, M. A.; Moran, M.; Vázquez, A.; Castillo, S. React. Kinet. Catal. Lett. 2007, 90, 381-387.

20. Lascalea, G. E.; Llamas, D. G.; Djurado, E.; Walsöe de Reca, N. E. J. Arg. Chem. Soc. 2003, 91, 135-142.

21. Reddy, B. M.; Sreekanth, P. M.; Lakshmanan, P.; Khan, A. J. Mol. Catal. A: Chem. 2006, 244, 1-7.

22. Ouqour, A.; Coudurier, G.; Vedrine, J. C. J. Chem. Soc. Faraday Trans. 1993, 89, 3151-3155.

23. Tomczak, D. C.; Allen, J. L.; Poeppelmeier, K. R. J. Catal. 1994, $146,155-165$.

24. Rekoske, J. E.; Barteau, M. A. J. Catal. 1997, 165, 57-72.

25. Moles, P. in: Zirconium Compounds in Catalysis: Current and Future Uses, Technical Report MEL CHEMICALS 1999, http:// www.zrchem.com.

26. Cid, R.; Pecchi, G. Appl. Catal. 1985, 14, 15-21.

27. Roskar, R.; Kmetec, V. Chem. Pharm. Bull. 2005, 53, 662-665.

28. Klewicki, R.; Konopacka, D.; Uczciwek, M.; Irzyniec, Z.; Piasecka, E.; Bonazzi, C. J. Hortic. Sci. Biotech. 2009, 84, 75-79.

29. Kalliopi A. Pore structure of cement-based materials. Testing, interpretation and requirements. Ed. Taylor and Francis Group, 2006.

30. Yori, J. C.; Pieck, C. L.; Parera, J. M. Catal. Lett. 2000, 64, 141146.

31. Pizzio, L.; Vázquez, P.; Cáceres, C.; Blanco, M. Catal. Lett. 2001, 77, 233-239.

32. Petre, A. L.; Auroux, A.; Gervasini, A.; Caldarau, M.; Ionescu, N. I. J. Therm. Anal. 2001, 64, 253-260.

33. Chary, K. V. R.; Seela, K. K.; Naresh, D.; Ramakanth, P. Catal. Commun. 2008, 9, 75-81.

34. Jin, T.; Yamaguchi, T.; Tanabe, K. J. Phys. Chem. 1986, 90, 47974805.

35. Morterra, C.; Cerrato, G.; Pina, F.; Signorreto, M. J. Catal. 1995, 157, 109-123.

36. White, R. L.; Sikabwe, E. C.; Coelho, M. A.; Resasco, P. E., J. Catal. 1995, 157, 755-758.

37. Yadav, G. D.; Nair, J. J. Micropor. Mesopor. Mater. 1999, 33, $1-48$.

38. Yori, J. C.; Parera J. M. Catal. Lett. 2000, 65, 205-208.

39. Stichert, W.; Schüth, F.; Kuba, S.; Knözinger, H. J. Catal. 2001, 198, 277-285.

40. Vera, C. R.; Pieck, C. L.; Shimizu, K.; Parera J. M. Appl. Catal. A. 2002, 230, 137-151.

41. Tomishige, K.; Akihiro, O.; Fujimoto, K. Appl. Catal. A. 2000, 194-195, 383-393. 